\begin{tabular}{|c|c|}
\hline & Volume \& Issues Obtainable at The Women University Multan \\
Annals of Social Sciences and Perspective \\
ISSN: 2707-7063, Volume 2, No.2 December 2021
\end{tabular}

\title{
Governance, Real Output and Foreign Direct Investment in Asia: A Panel Data Analysis
}

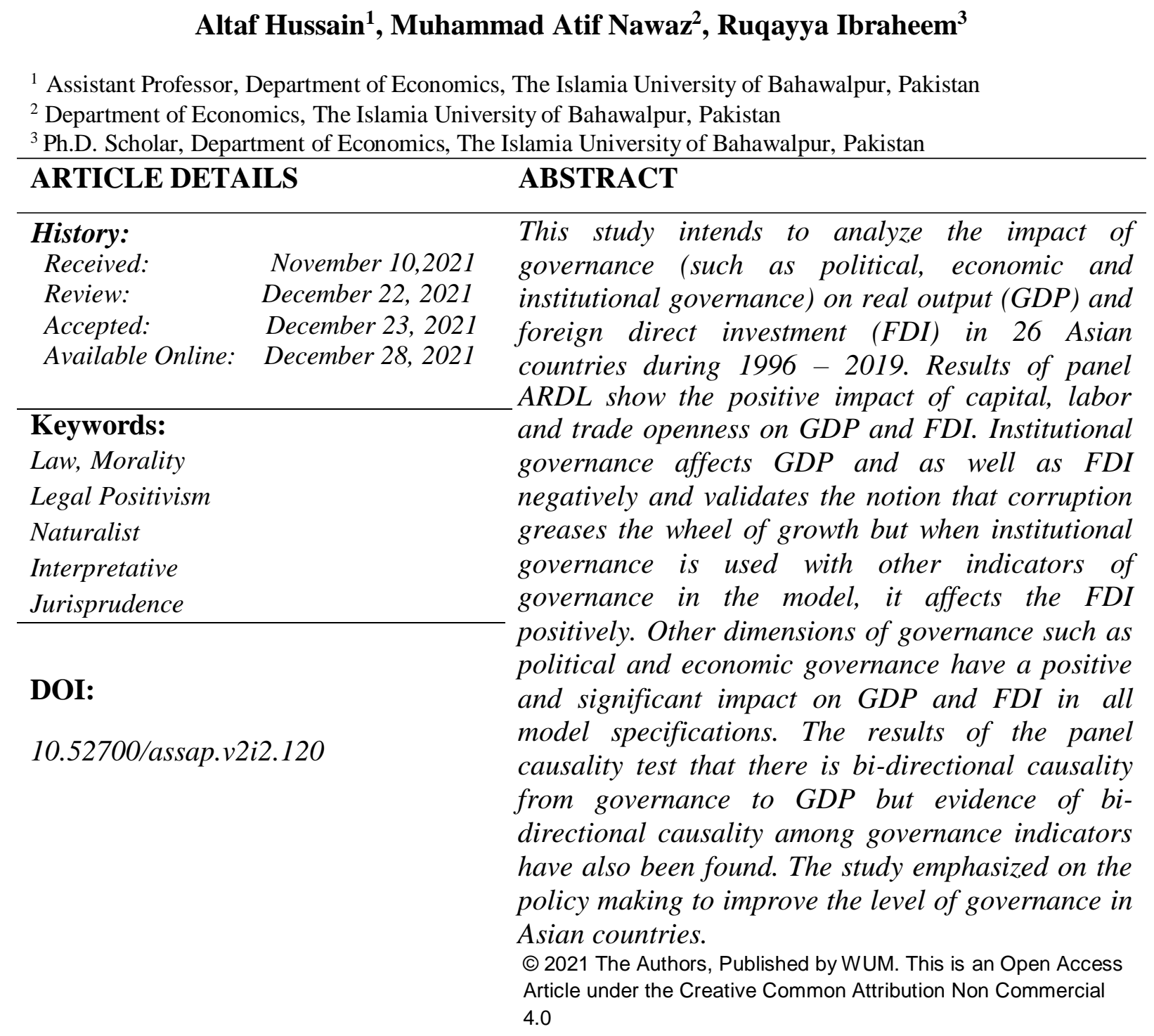

Corresponding author's email address: ruqayyaibraheem13@gmail.com

\section{Introduction}

Every nation strives for economic development which translates into human well-being. But development is not a purely economic concept rather a polygonal course of action involving the restructuring and reforming of the economic, political and social system. Initially, economic fundamentals, after being identified by economic historians, were focused in 
economic policy making. It has been learned from the experience of advanced as well as third world countries that economic policies only work in such a country where good governance is of utmost preference not only in the public sector but in the private sector also because both are two sides of development coin. In addition to improvements in income levels, profound improvements in institutional and administrative structures, as well as popular attitudes and even customs and beliefs of society, are imperative for economic development. The relationship between governance and development has been exceptionally wrangled about the point in the Asian setting. While a few academic practitioners contend that governance demonstrates constructive outcomes on development, others are of the view that it is not the situation. Governance builds up the structure for economic actions inside a nation. Impressive governance on one hand can make a situation that advances financial movement, gives motivating forces to contribute to economic development. Terrible governance then again can negatively affect economic development by expanding exchange costs and by bringing about deferrals in the speculation procedure (Gani, 2011; Kaufmann, Kraay, Lora, \& Pritchett, 2002).

With the start of the industrial revolution in the 1760s initiated from Great Britain, economic growth in terms of higher production was advocated by economists through their classical growth theory. Classical growth theories are categorized as theories of saving, investment and foreign trade, which are still considered as the main ingredients of economic growth. Keynes, being the most influential economist of the 20th century, advocated the role of consumption, investments, government spending and net export in the aggregate economy of a country. Theorists of the 1950 and 1960 viewed the process of development as a series of successive stages of economic growth through which all the counties must pass. A proponent of structural change growth theory supported the reallocation of agricultural labor to the technologically advanced industrial sector with positive marginal productivity to absorb surplus labor of agriculture and increase the output of the industrial sector.

It has been asserted by researchers from all around the world that a good political environment breeds a good business environment which is favorable for investor confidence in the economy. Regulatory quality and government effectiveness can affect technical efficiency leading to high economic growth rates (Habtamu, 2008). Political stability and good governance promote economic growth (Zubair \& Khan, 2014). Governance can also have an impact on foreign direct investment which is considered to be an important determinant of economic growth. Developing countries should focus on improving the quality of domestic institutions to attract foreign inflows (Bénassy-Quéré, Coupet, \& Mayer, 2007). Even countries with a larger pool of natural resources can never achieve economic growth without focusing on good governance. Previous literature on economic growth in the governance context reveals that a lot of researches have been conducted on individual countries and the individual regions or groups based on similar features of economy and government. The development process among Asian countries is not the same for every country in the region. Some countries have a tremendous development trajectory but others have not been successful in this pursuit (ESCAP, 2017). UNDP administrator contended that "without good governance, countries will find it too much difficult to achieve and sustain development outcomes". Better governance enhances the capacity of the economy to develop with innovative processes and having access to a skilled and trained labor force. Furthermore, governance also improves the country's investment prospects. Governance is very imperative to achieve Sustainable Development Goals 8 and 9 which are necessary to target Agenda 2030 .

Therefore, it is vital to investigate the impact of governance on real output (Gross Domestic Product) and Foreign Direct Investment. Hence, this study intends to analyze the impact of 
World Governance Indicators on economic growth and foreign direct investment in Asia. This is a comprehensive empirical study that is aimed to point out the difference in economic output across Asian countries on the one hand and significant variations in foreign direct investment among these countries.

\section{Literature Review}

Aparicio, Urbano, and Audretsch (2016) examined the effects of informal institutional factors (control of corruption and confidence in one's skills) and formal institutional factors like private coverage to obtain credit and number of procedures to start a new business on entrepreneurship and its impact on economic growth consequently and found a positive and significant impact of informal institutional factors rather formal factors on economic growth through transitory variable opportunity entrepreneurship. Theoretical channels through which institutional governance collaborates with education and has an impact on economic growth are analyzed by Jellal, Mohamed, and Asongu (2016). Azam and Emirullah (2014) explored the effects of corruption as a crucial indicator of bad governance along with inflation rate, openness to trade and dependency ratio as control variables on GDP per capita of selected countries of Asia and Pacific and confirmed that good governance reduced corruption and control inflation and important factor for policymakers.

Wilson (2016) analyzed the growth-governance hypothesis along with governance-growth hypothesis on the provincial level in China and found that economic growth bred the highquality governance in provinces in China rather than governance procreated the economic growth. In this study, China's economic growth is associated with informal governance through cooperative standards and the social web. Huang (2016) examined the causality between corruption and economic growth in Asia-Pacific countries. The results were opposite to the general perception that corruption negatively affects economic growth. This study concluded with the positive causality running from corruption to economic growth specifically in South Korea and causality from economic growth to corruption was found in the case of China. Farooq, Shahbaz, Arouri, and Teulon (2013) reinvestigated the shock of corruption on economic growth in Pakistan by interacting with financial development and trade openness in the corruption-growth model. The study shows that corruption impedes economic growth. But financial development and trade openness boost economic growth by influencing capitalization and domestic production respectively.

Vìtola and Šenfelde (2014) highlighted the effects of traditions and institutions on socioeconomic performance in 202 countries. The World Governance Indicators were closely related to socio-economic development in terms of GDP per capita and life expectancy at birth. Public expenditures and tertiary school enrollment are affected by governance on the world level but on the European level governance increases the unemployment level and deteriorates the GINI index. In efficiency driven economies, voice and accountability proved to be the main influencer of economic activity. But rule of law and regulatory quality was confirmed to affect economic pursuits in factor-driven economies. Government effectiveness is pointed out as a significant factor of socio-economic performance in all groups of countries.

Other than the conventional determinants of economic growth, Yerrabati and Hawkes (2015) did a study in the Asian context using 29 studies and 554 estimates from 1980-2012. A negative and significant correlation had been identified between governance in terms of 
political stability, government effectiveness, regulation and rule of law, and economic growth for which change of government rather than a long lasting one has been suggested in the study. While control of corruption and voice and accountability have a significant and positive relationship with growth. Zubair and Khan (2014) to check the relationship between Worldwide Governance Indicators (WGI) and economic growth in Pakistan and found that all the variables affected the economic growth insignificantly except political instability.

Sarwar, Afzal, Shafiq, and Rehman (2013) predicted the relationship between the institution and economic growth in selected countries of South Asia and indicated that institutional index, population growth, physical capital growth, education index and inflation positive and significant impact on real GDP index. Nazir and Anwar (2013) analyzed that the role of governance or institutional factors to explain variation in GDP growth of Pakistan empirically and recognized the positive role of governance for economic growth.

In the context of Pakistan, Haider, ud Din, and Ghani (2011) examined the impact of governance in terms of the political administration of different in-powered political parties and their corruption on inflation and economic growth. A positive and significant relationship was inferred in the study. Governance-Growth model was disaggregated based on income groups by Cooray (2009). In this study significance of government in terms of quality and size is highlighted empirically. It was argued that correct use of public expenditures can result in sound quality institutions which can ultimately foster growth in the economy. Haq, Zia, and Arif (2006) explored the linkage between governance and economic growth in Pakistan and showed that governance indicators (VA, PV, RQ, and RL) exhibit a negative and significant relationship with poverty and income inequality GE positively \& insignificantly associated. The study concluded Pakistan needs to formulate and effectively implement its governance policies to improve governance dimensions, taking account for higher growth. Ahmad, Bashir, and Hussain (2018) also found that good governance accompanied with human capital improvements reduces poverty significantly in developing countries.

\subsection{Studies on Foreign Direct Investment and Governance}

Hoa and Lin (2016) probed into the economic, institutional and political factors of inward FDI in Cambodia, Laos and Vietnam (Indochina). Results of the Random effect model showed a significant and positive impact of political stability, government effectiveness, and rule of law and market size on foreign direct investment (FDI).

Long, Yang, and Zhang (2015) tested the FDI-induced institutional improvement argument empirically in China. Three different panels of firm level datasets compiled by the World Bank and a private organization were used for analysis. The empirical evidence of the study revealed that a higher level of FDI is associated with a higher level of institutional quality in terms of low tax and free burden along with improvement in rule of law. This study pointed out a very interesting channel through which FDI can improve the institutional quality in the host country and may contribute towards its long-run economic growth. FDI's spillovers other than technological ones were suggested to be considered during policy making.

Méon and Sekkat (2005) studied the impact of institutional quality and political regime on foreign direct investment (FDI). Results showed that one time increase in standard deviation in the property rights index was associated with a $40 \%$ increase in FDI. It was also evident from the results of the study that commitment to better institutions is associated with an 
autocratic regime. The study concluded with the findings that it is not the form of government but institutional factors that are most important for any investor on which their investment decisions are based.

Zeshan and Talat (2014) determined the relationship between inflows of foreign direct investment and world governance indicators (WGI) in the case of Pakistan's economy. All governance indicators used in this study have a significant relationship with foreign inflows. Policy makers and regulatory authorities are advised to improve the condition of governance in the country to attract foreign inflows. The influence of different governance indicators on foreign direct investment was estimated by Gani (2007) and found that governance and FDI have a positive and significant relationship with each other.

Habib and Zurawicki (2002) investigated the link between corruption and foreign direct investment. The study was concluded with the negative impact of the Corruption Perception Index (CPI) and the difference in Corruption Perception Index between home and host country on FDI. Other variables like population, GDP, unemployment, trade openness, science and technology and distance have positive effects on FDI as far as countries' studies were concerned.

Globerman, Shapiro, and Tang (2006) tried to examine factors of FDI (inward and outward) in emerging Europe. A panel of 138 countries was constructed for analytical purposes, most importantly to investigate the inward and outward FDI in emerging and former Europe. The results showed a positive and significant relationship between the governance index and FDI. Besides this, privatization and trade are also important indicator of inward FDI but stock market liquidity in the form of market capitalization have a strong impact on outward FDI. GDP is also proved to be a good indicator of FDI in developing countries of Europe.

Globerman and Shapiro (2003) analyzed the role of governance framework in attracting FDI into the domestic country and stimulating FDI from these countries to other foreign countries. It was argued after findings of the study that open and clear legal and regularity quality and effective provisions of public goods promote competition not only in the domestic economy but also in international settings thereby stimulating inflows and outflows of FDI and these factors proved to be more effective than political voice and stability and rule of law. On the other hand, human capital in terms of education only affects FDI inflows. Environmental sustainability and investment in governance infrastructure are also proved to be a significant indicators of FDI.

\section{Model, Data and Methodology}

\subsection{Model Specification}

\section{Model 1: Governance-Real Output Model}

In the governance-real output model, labor and capital represent the main ingredients of the Solow growth model and political, economic and institutional governance are used as policy variables.

Real GDP $=f($ Labor, Capital, governance, Control Variables $)$ 


$$
\begin{aligned}
& \quad R G D P^{*}=\beta_{0 i}^{*}+\beta \underset{1 i}{L F}+\beta_{i t} R G F C F_{i t}+\beta_{3 i} C C_{i t}+\beta P_{4 i} P G O V_{i t}+\beta_{5 i} E G O V_{i t}+\beta_{6 i}^{I G O V_{i t}^{+}}+ \\
& \beta_{i} C V_{i t}{ }^{*}+w_{i t}
\end{aligned}
$$

By including control variables;

$$
\text { Real GDP }=f\left\{\begin{array}{c}
\text { Capital, } \text { Labor, } \text { Politial governance, Economic governance, } \\
\text { Institutional governance, } \text { Trade Openness }
\end{array}\right\}
$$

$R G D P^{*}=\beta_{0 i}{ }^{*}+\beta_{1 i} L F_{i t}+\beta_{2 i} R G F C F_{i t}+\beta_{3 i} C C_{i t}+\beta_{4 i} P G O V_{i t}+\beta_{5 i} E G O V_{i t}+\beta_{6 i} I G O V_{i t}+$ $\beta_{7 i} T O_{i t}{ }^{*}+w_{i t}$

Where:

$$
\begin{aligned}
& \text { RGDP }{ }^{*}=\text { Real Gross Domestic Product } \\
& \text { LF }=\text { Total Labor Force } \\
& \text { RGFCF }=\text { Real Gross Fixed Capital Formation } \\
& \text { PGOV= Political Governance } \\
& \text { EGOV= Economic Governance } \\
& \text { IGOV= Institutional Governance } \\
& \text { TO=Log of Trade Openness }
\end{aligned}
$$

\section{Model 2: Governance-FDI Model}

The governance-FDI model is as follows:

Real FDI $=f($ Labor, Capital, governance, Control Variables $)$

$R F D I^{*}=\beta_{0 i}{ }^{*}+\beta_{1 i} L F_{i t}+\beta_{2 i} R G F C F_{i t}+\beta_{3 i} C C_{i t}+\beta_{4 i} P G O V_{i t}+\beta_{5} E G O V_{i t} \beta_{6} G G O V_{\text {it }} \beta_{i i} V_{i t}^{*}+$ $w_{i t}$

By including control variables;

$$
\begin{gathered}
\text { Real FDI }=f\left\{\begin{array}{c}
\text { Capital, Labor, Politial governance, Economic governance, } \\
\text { Institutional governance, Trade Openness }
\end{array}\right\} \\
\text { RFDI }^{*}=\beta_{0 i}^{*}+\beta_{1 i} L F_{i t}+\beta_{2 i} R G F C F_{i t}+\beta_{3 i} C C_{i t}+\beta_{4 i} P_{i t} G O V_{i t}+\beta_{5 i} E G O V_{i t}+\beta_{6 i} I G O V_{i t}+ \\
\beta_{i t}+w_{i t}
\end{gathered}
$$

Where: 


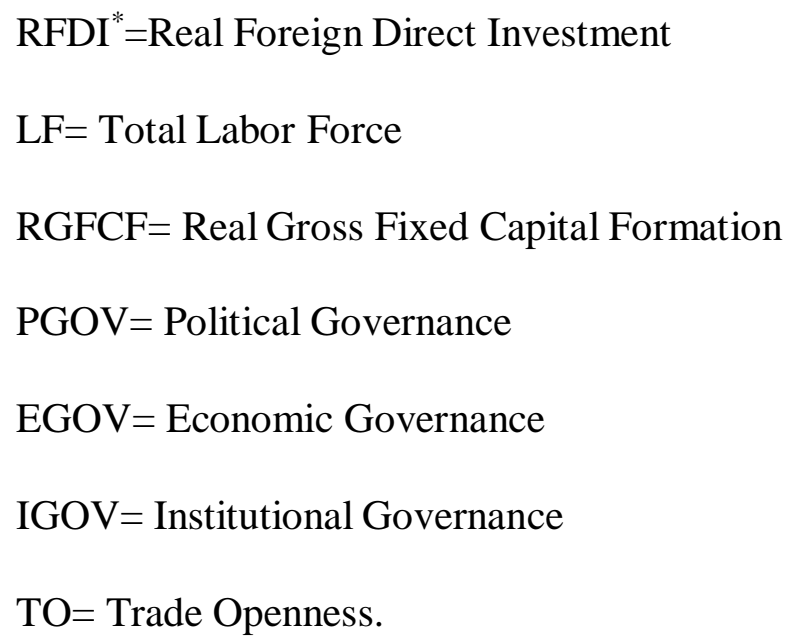

\subsection{Data: Sources and Definition}

Data from World Atlas revealed that there are almost 48 countries in Asia. Because of the unavailability of data on countries, a panel data set comprising 26 economies of Asia (list of countries is given in Appendix) from 1996 to 2019 is used to investigate the governanceoutput and governance-FDI relationships in the context of Asia. All variables used in the analysis are tabulated in form of measurement, data source and expected relationship with the dependent variable in Table 1.

Table 1: Variable Description and Expected Relationships

\begin{tabular}{|c|c|c|c|c|c|}
\hline S. No. & Variables & $\begin{array}{l}\text { Dependent or } \\
\text { Independent }\end{array}$ & Unit of Measurement & Data Source & $\begin{array}{l}\text { Expected } \\
\text { Relationship }\end{array}$ \\
\hline 01 & GDP & D.V. & Millions of US \$ & WDI & - \\
\hline 02 & FDI & D.V. & Millions of US \$ & WDI & - \\
\hline 03 & GFCF & I.V. & Millions of US \$ & WDI & $\begin{array}{l}\text { Positive/ } \\
\text { Negative }\end{array}$ \\
\hline 04 & Labor Force & I.V. & Millions Unit & WDI & Positive \\
\hline 05 & Trade Openness & I.V. & $\begin{array}{l}\text { The total size of trade } \\
\text { relative to GDP }\end{array}$ & WDI & $\begin{array}{l}\text { Positive/ } \\
\text { Negative }\end{array}$ \\
\hline 06 & PGOV & I.V. & Composite Index by CPA & $\begin{array}{l}\text { Calculated by } \\
\text { author based } \\
\text { on WGI }\end{array}$ & $\begin{array}{l}\text { Positive/ } \\
\text { Negative }\end{array}$ \\
\hline 07 & EGOV & I.V. & Composite Index by CPA & $\begin{array}{l}\text { Calculated by } \\
\text { author based } \\
\text { on WGI }\end{array}$ & $\begin{array}{l}\text { Positive/ } \\
\text { Negative }\end{array}$ \\
\hline 08 & IGOV & I.V. & Composite Index by CPA & $\begin{array}{l}\text { Calculated by } \\
\text { author based } \\
\text { on WGI }\end{array}$ & $\begin{array}{l}\text { Positive/ } \\
\text { Negative }\end{array}$ \\
\hline 09 & GOV & I.V. & Composite Index by CPA & $\begin{array}{l}\text { Calculated by } \\
\text { author based } \\
\text { on WGI }\end{array}$ & $\begin{array}{l}\text { Positive/ } \\
\text { Negative }\end{array}$ \\
\hline
\end{tabular}

Note: Table is Author's own construct based on previous studies related to governance-GDP and governance-FDI relationships. 


\subsection{Panel Unit Root Test}

Table 2 shows the result of Levin, Lin, Chu panel unit root test that was applied to the different data series used in this study. Results are discussed variable-wise after the table.

Table 2: Results of Levin, Lin, Chu (Unit Root Test)

\begin{tabular}{|c|c|c|c|c|c|c|}
\hline \multirow{3}{*}{ Variable } & \multirow{3}{*}{ Unit Root in } & \multicolumn{4}{|c|}{ Levin, Lin, Chu Panel Unit Root Test } & \multirow{3}{*}{ Decision } \\
\hline & & \multicolumn{2}{|c|}{ Level } & \multicolumn{2}{|c|}{$\mathbf{1}^{\text {st }}$ Difference } & \\
\hline & & Stat & P-value & Stat & P-value & \\
\hline \multirow{2}{*}{ LRGDP } & Intercept & 4.5588 & 1.0000 & -5.1469 & 0.0000 & \multirow{2}{*}{$\mathrm{I}(0)$} \\
\hline & Intercept \& Trend & -2.4351 & $0.0074^{*}$ & -3.8913 & 0.0000 & \\
\hline \multirow{2}{*}{ LRFDI } & Intercept & 0.7366 & 0.7366 & -7.8583 & $0.0000^{*}$ & \multirow{2}{*}{$\mathrm{I}(1)$} \\
\hline & Intercept \& Trend & 0.2005 & 0.5795 & -5.8341 & 0.0000 & \\
\hline \multirow{2}{*}{ LRGFCG } & Intercept & 2.2403 & 0.9875 & -5.8436 & 0.0000 & \multirow{2}{*}{$\mathrm{I}(0)$} \\
\hline & Intercept \& Trend & -2.9730 & $0.0015^{*}$ & -3.1804 & 0.0007 & \\
\hline \multirow{2}{*}{ LLF } & Intercept & -5.3006 & $0.0000^{*}$ & -0.3882 & 0.3489 & \multirow{2}{*}{$\mathrm{I}(0)$} \\
\hline & Intercept \& Trend & -1.0541 & 0.1459 & 2.5885 & 0.9952 & \\
\hline \multirow{2}{*}{ TO } & Intercept & -1.4678 & 0.0711 & -11.8661 & 0.0000 & \multirow{2}{*}{$\mathrm{I}(0)$} \\
\hline & Intercept \& Trend & -3.057 & $0.0011^{*}$ & -10.8783 & 0.0000 & \\
\hline \multirow{2}{*}{ PGOV } & Intercept & -2.3947 & $0.0083^{*}$ & -10.3042 & 0.0000 & \multirow{2}{*}{$\mathrm{I}(0)$} \\
\hline & Intercept \& Trend & -0.7304 & 0.2326 & -7.3663 & 0.0000 & \\
\hline \multirow{2}{*}{ EGOV } & Intercept & -1.6116 & 0.0535 & -11.3708 & $0.0000^{*}$ & \multirow{2}{*}{$\mathrm{I}(1)$} \\
\hline & Intercept \& Trend & -1.3477 & 0.0889 & -8.6565 & 0.0000 & \\
\hline \multirow{2}{*}{ IGOV } & Intercept & -0.9930 & 0.1604 & -7.8527 & $0.0000^{*}$ & \multirow{2}{*}{$\mathrm{I}(1)$} \\
\hline & Intercept \& Trend & 1.0756 & 0.8589 & -4.9971 & 0.0000 & \\
\hline \multirow{2}{*}{ GOV } & Intercept & -1.2112 & 0.1128 & -7.9968 & $0.0000^{*}$ & \multirow{2}{*}{$\mathrm{I}(1)$} \\
\hline & Intercept \& Trend & 0.9168 & 0.8204 & -5.1118 & 0.0000 & \\
\hline
\end{tabular}

Source: Author's own calculations using E-views 9 based on the data from WDI and WGI.

NOTE: ${ }^{*}$ and ${ }^{* *}$ show the $1 \%$ and $5 \%$ levels of significance.

Keeping in view the results presented in the above table, it has been revealed that data series of gross domestic product, gross fixed capital formation, labor force, trade openness and political governance are stationary at level but other variables.

(foreign direct investment, economic governance, institutional governance and overall governance) used in the study are stationary at 1st difference. Therefore, it is most appropriate to use the pooped mean group autoregressive distributive lag (PMG, ARDL) technique to estimate the econometric relationships between governance, real output and foreign direct investment.

\section{Results and Discussion}

\subsection{Panel ARDL, Long Run Results (Governance and Real Output)}

The long run results of panel ARDL are presented in table 3 showing results for eight different econometric models. The results presented in table 3 reveal surprisingly that institutional governance has negative as well as a positive impact on economic growth but this is not against economic rationality. Positive impact on real output is significant in model three when institutional governance is used solely as an indicator of governance meaning that institutional governance has a significant impact on the gross domestic product but it 
becomes negative and significant by introducing the other dimensions of governance in the model 8. The negative impact of institutional governance in Asia means that as far as corruption is controlled in the country economic growth will be retarded. In countries, political agents exercised their powers in private gains or even machinery of the whole structure of the economy take bribes for different legal permissions. Our results for institutional governance reveal that corruption increases economic growth (corruption grease the wheel of growth) and control of corruption retards economic growth. These results are consistent with the results obtained by Wedeman (1997), Méon and Sekkat (2005) and Huang (2016). Additionally, Ouédraogo (2017) was of the view that corruption and poor institutional arrangements support the informal economy.

Economic governance has a positive and statistically significant impact on gross domestic product. This finding provides robust support to the idea that government effectiveness in terms of effective policies and credibility enhance economic growth, especially in developing countries by providing good public and civil services, formulation of effective public policies and commitment to implement these, reducing red tape and overall credibility of the government.

\section{Table 3: Panel ARDL, Long Run Results (Dependent Variable: Gross Domestic Product).}

\begin{tabular}{|c|c|c|c|c|c|c|c|c|}
\hline Model No. & 1 & 2 & 3 & 4 & 5 & 6 & 7 & 8 \\
\hline (Lag Length) & $(2,2,2,2,2)$ & $(2,2,2,2,2)$ & $(2,2,2,2,2)$ & $(2,2,2,2,2)$ & $(2,2,2,2,2)$ & $(2,2,2,2,2)$ & $(2,2,2,2,2)$ & $(2,2,2,2,2,2,2)$ \\
\hline \multirow{2}{*}{ Capital } & 0.8808 & 0.8880 & 0.8725 & 0.8784 & 0.8768 & 0.8810 & 0.8816 & 0.7779 \\
\hline & $(0.0000)^{*}$ & $(0.0000)^{*}$ & $(0.0000)^{*}$ & $(0.0000)^{*}$ & $(0.0000)^{*}$ & $(0.0000)^{*}$ & $(0.0000)^{*}$ & $(0.0000)^{*}$ \\
\hline \multirow{2}{*}{ Labor } & 0.4843 & 0.0351 & 0.5788 & 0.4861 & 0.3253 & 0.5729 & 0.4466 & 0.6344 \\
\hline & $(0.0000)^{*}$ & $(0.5522)$ & $(0.0000)^{*}$ & $(0.0000)^{*}$ & $(0.0000)^{*}$ & $(0.0000)^{*}$ & $(0.0000)^{*}$ & $(0.0000)^{*}$ \\
\hline \multirow{2}{*}{$\begin{array}{l}\text { Trade } \\
\text { openness }\end{array}$} & 0.0779 & -0.0399 & -0.0025 & -0.0427 & -0.0707 & 0.0219 & 0.0067 & 0.0018 \\
\hline & $(0.0011)^{*}$ & $(0.1396)$ & $(0.9268)$ & $(0.0940)$ & $(0.0103)^{* * *}$ & $(0.3589)$ & $(0.7787)$ & $(0.9717)$ \\
\hline $\begin{array}{l}\text { Political } \\
\text { Governance }\end{array}$ & $\begin{array}{l}0.0495 \\
(0.0001)^{*}\end{array}$ & - & - & - & - & - & - & $\begin{array}{l}0.0277 \\
(0.0503)^{* *}\end{array}$ \\
\hline $\begin{array}{l}\text { Economic } \\
\text { Governance }\end{array}$ & - & $\begin{array}{l}0.1059 \\
(0.0000)^{*}\end{array}$ & - & - & - & - & - & $\begin{array}{l}0.2135 \\
(0.0000)^{*}\end{array}$ \\
\hline $\begin{array}{l}\text { Institutional } \\
\text { Governance }\end{array}$ & - & - & $\begin{array}{l}0.0961 \\
(0.0001) \\
\end{array}$ & - & - & - & - & $\begin{array}{l}-0.3869 \\
(0.0000)^{*}\end{array}$ \\
\hline $\begin{array}{l}\text { Overall } \\
\text { Governance }\end{array}$ & - & - & - & $\begin{array}{l}0.0618 \\
(0.0000)^{*}\end{array}$ & - & - & - & - \\
\hline $\begin{array}{l}\text { Institutional } \\
\text {-Economic }\end{array}$ & - & - & - & $x_{1}$ & $\begin{array}{l}0.1196 \\
(0.0000)^{*}\end{array}$ & - & - & - \\
\hline $\begin{array}{l}\text { Institutional } \\
\text {-Political }\end{array}$ & - & - & - & - & - & $\begin{array}{l}0.0715 \\
(0.0000)^{*}\end{array}$ & - & - \\
\hline $\begin{array}{l}\text { Economic } \\
\text {-Political }\end{array}$ & - & & - & - & - & & $\begin{array}{l}0.0647 \\
(0.0000)^{*}\end{array}$ & - \\
\hline
\end{tabular}


Source: Author's estimation based on WDI \& WGI Data

Note: $*$ and $* *$ represents 1 and 5 percent level of significance correspondingly. Probabilities for each coefficient are given in parentheses.

Macroeconomic stability and public expenditures accompanying good governance in the public sector can pay off the country with higher economic growth (Pushak, Tiongson, \& Varoudakis, 2007). The study conducted by Fischer, Alonso-Gamo, and Von Allmen (2001) that perception of poor governance, extreme red tape and inefficiencies in financial management and bureaucracy can deter economic growth. The positive effect of government effectiveness in economic affairs has also been evidenced in previous studies (Asghar, Qureshi, \& Nadeem, 2020; Bhattacharjee \& Haldar, 2015; Cooray, 2009; Gani, 2011; Wilson, 2016).

Table 4: Panel ARDL, Short Run Results (Dependent Variable: Gross Domestic Product)

\begin{tabular}{|c|c|c|c|c|c|c|c|c|}
\hline Model No. & 1 & 2 & 3 & 4 & 5 & 6 & 7 & 8 \\
\hline (Lag Length) & $(2,2,2,2,2)$ & $(2,2,2,2,2)$ & $(2,2,2,2,2)$ & $(2,2,2,2,2)$ & $(2,2,2,2,2)$ & $(2,2,2,2,2)$ & $(2,2,2,2,2)$ & $(2,2,2,2,2,2,2)$ \\
\hline & -0.3685 & -0.3704 & -0.3602 & -0.3889 & -0.3454 & -0.3849 & -0.3976 & -0.2060 \\
\hline \multicolumn{9}{|l|}{ ECT } \\
\hline & $(0.0000)$ & $(0.0000)$ & $(0.0000)$ & $(0.0000)$ & $(0.0000)$ & $(0.0000)$ & $(0.0000)$ & $(0.0000)$ \\
\hline & 0.1155 & 0.0413 & 0.0967 & 0.0806 & 0.0143 & 0.1154 & 0.1367 & 0.0713 \\
\hline \multicolumn{9}{|l|}{$\mathrm{D}(\mathrm{GDP}(-1))$} \\
\hline & $(0.1347)$ & $(0.6079)$ & $(0.1491)$ & $(0.2954)$ & $(0.5972)$ & $(0.1175)$ & $(0.0737)$ & $(0.2971)$ \\
\hline & 0.3333 & 0.3137 & 0.3613 & 0.3231 & 0.3513 & 0.3337 & 0.3073 & 0.4067 \\
\hline \multicolumn{9}{|l|}{ D (Capital) } \\
\hline & $(0.0000)$ & $(0.0000)$ & $(0.0000)$ & $(0.0000)$ & $(0.0000)$ & $(0.0000)$ & $(0.0001)$ & $(0.0000)$ \\
\hline \multirow{2}{*}{$\begin{array}{c}\text { D (Capital (- } \\
1))\end{array}$} & 0.2254 & -0.1607 & -0.1959 & -0.1962 & -0.1554 & -0.2221 & -0.2461 & -0.3129 \\
\hline & $(0.0001)$ & $(0.0067)$ & $(0.0004)$ & $(0.0004)$ & $(0.0087)$ & $(0.0001)$ & $(0.0000)$ & $(0.0009)$ \\
\hline & 0.1735 & 0.8169 & 0.1668 & 0.6014 & 0.5771 & 0.3334 & 0.5079 & 0.0512 \\
\hline \multicolumn{9}{|l|}{ D (Labor) } \\
\hline & $(0.7376)$ & $(0.1057)$ & $(0.7021)$ & $(0.2533)$ & $(0.2547)$ & $(0.5107)$ & $(0.3297)$ & $(0.9042)$ \\
\hline \multirow{2}{*}{$\begin{array}{c}\text { D (Labor (- } \\
1))\end{array}$} & -1.1344 & -1.4904 & -1.3036 & -1.5754 & -1.3731 & -1.3177 & -1.5400 & -1.2532 \\
\hline & (0.1154) & $(0.1281)$ & (0.1238) & $(0.0489)$ & $(0.1053)$ & $(0.0717)$ & $(0.0520)$ & $(0.0913)$ \\
\hline & -0.0858 & -0.1135 & -0.0654 & -0.0488 & -0.0668 & -0.0562 & -0.0638 & -0.1298 \\
\hline \multirow{2}{*}{$\mathrm{D}(\mathrm{T} \mathrm{O})$} & & & & & & & & \\
\hline & $(0.3365)$ & $(0.1562)$ & $(0.4943)$ & $(0.6232)$ & $(0.4796)$ & $(0.4748)$ & $(0.4760)$ & $(0.1088)$ \\
\hline & -0.0555 & 0.0366 & $\begin{array}{l}-0.0288 \\
\end{array}$ & -0.0039 & 0.0038 & -0.0562 & $\begin{array}{l}-0.0072 \\
\end{array}$ & -0.0213 \\
\hline \multicolumn{9}{|l|}{$\mathrm{D}(\mathrm{T} O(-1)$} \\
\hline & $(0.5088)$ & $(0.7434)$ & $(0.6827)$ & $(0.9650)$ & $(0.9675)$ & $(0.4707)$ & $(0.9401)$ & $(0.8413)$ \\
\hline & $\begin{array}{l}-0.0149 \\
\end{array}$ & & & & & & & 0.0219 \\
\hline \multirow[t]{2}{*}{$\mathrm{D}(\mathrm{PGOV})$} & & - & - & - & - & - & - & \\
\hline & $(0.4557)$ & & & & & & & $(0.2335)$ \\
\hline \multirow{3}{*}{$\begin{array}{c}\mathrm{D}(\mathrm{PGOV}(- \\
1)\end{array}$} & 0.0012 & & & & & & & 0.0734 \\
\hline & & & - & - & - & - & - & \\
\hline & $(0.9672)$ & & & & & & & $(07384)$ \\
\hline \multirow{3}{*}{ D (EGOV) } & & -0.0595 & & & & & & -0.0188 \\
\hline & - & & - & - & - & - & - & \\
\hline & & $(0.0571)$ & & & & & & $(0.5826)$ \\
\hline \multirow{3}{*}{$\begin{array}{c}\mathrm{D}(\mathrm{EGOV}(- \\
1)\end{array}$} & & -0.0369 & & & & & & -0.1932 \\
\hline & - & & - & - & - & - & - & \\
\hline & & $(0.2061)$ & & & & & & $(0.2317)$ \\
\hline \multirow{3}{*}{ D (IGOV) } & & & -0.0717 & & & & & 0.0604 \\
\hline & - & - & & - & - & - & - & \\
\hline & & & $(0.0002)$ & & & & & $(0.1034)$ \\
\hline
\end{tabular}




\begin{tabular}{|c|c|c|c|c|c|c|c|c|}
\hline $\begin{array}{c}\mathrm{D}(\mathrm{IGOV}(- \\
1)\end{array}$ & - & - & $\begin{array}{l}-0.0768 \\
(0.0556)\end{array}$ & - & - & - & - & $\begin{array}{l}0.0972 \\
(0.0621)\end{array}$ \\
\hline & & & & -0.0345 & & & & \\
\hline $\mathrm{D}(\mathrm{GOV})$ & - & - & - & $(0.0627)$ & - & - & - & - \\
\hline $\mathrm{D}(\mathrm{GOV}(-1)$ & - & - & - & $\begin{array}{l}-0.0223 \\
(0.3975)\end{array}$ & - & - & - & - \\
\hline $\mathrm{D}(\mathrm{I} * \mathrm{EGOV})$ & - & - & - & - & $\begin{array}{l}-0.0722 \\
(0.0185) \\
\end{array}$ & - & - & - \\
\hline $\begin{array}{c}\text { D (I*EGOV } \\
(-1)\end{array}$ & - & - & - & - & $\begin{array}{l}-0.0613 \\
(0.1270)\end{array}$ & - & - & - \\
\hline $\mathrm{D}(\mathrm{I} * \mathrm{PGOV})$ & - & - & - & - & - & $\begin{array}{l}-0.0332 \\
(0.1008)\end{array}$ & - & - \\
\hline $\begin{array}{c}\mathrm{D}(\mathrm{I} * \mathrm{PGOV} \\
(-1)\end{array}$ & - & - & - & - & - & $\begin{array}{l}-0.0279 \\
(0.4116)\end{array}$ & - & - \\
\hline $\begin{array}{c}\mathrm{D} \\
\left(\mathrm{E}^{*} \mathrm{PGOV}\right)\end{array}$ & - & - & - & - & - & - & $\begin{array}{l}-0.0234 \\
(0.2168)\end{array}$ & - \\
\hline $\begin{array}{c}\mathrm{D}\left(\mathrm{E}^{*} \mathrm{PGOV}\right. \\
(-1)\end{array}$ & - & - & - & - & - & - & $\begin{array}{l}0.0113 \\
(0.7283) \\
\end{array}$ & - \\
\hline Constant & $\begin{array}{l}-1.3786 \\
(0.0000)\end{array}$ & $\begin{array}{l}1.8238 \\
(0.0000)\end{array}$ & $\begin{array}{l}-1.8341 \\
(0.0000)\end{array}$ & $\begin{array}{l}-1.3978 \\
(0.0000) \\
\end{array}$ & $\begin{array}{l}-0.2951 \\
(0.0000)\end{array}$ & $\begin{array}{l}-2.0001 \\
(0.0000)\end{array}$ & $\begin{array}{l}-1.2106 \\
(0.0000)\end{array}$ & $\begin{array}{l}-0.8287 \\
(0.0002)\end{array}$ \\
\hline
\end{tabular}

Source: Author's estimation based on WDI \& WGI Data by using Eviews-9.

Note: $*$ and $* *$ represents 1 and 5 percent level of significance correspondingly. Probabilities for each coefficient are given in parentheses.

Like economic governance, political governance also has a positive and significant effect on economic growth. By means of political stability, accountability of political and administrative agents, freedom of speech and unlikelihood of crime and violence, the economic output can be increased. As aforementioned dimensions of political governance can affect investor confidence positively and can spur entrepreneurial activities. Haidar (2012) concluded in his study on 172 countries by using micro-level dataset that enacting and enforcing business reforms laws leads to economic growth significantly. Bjørnskov (2012) social political stability and the absence of violence directly affect social trust and schooling and thereby economic growth positively. This positive and significant impact of political governance on economic growth (GDP) is consistent with the findings of previous studies (Asghar et al., 2020; Haggard \& Tiede, 2011; Huang \& Ho, 2017; Ouédraogo, 2017).

\subsection{Panel ARDL, Short Run Results (Governance and Real Output)}

Table 4 demonstrated the results of short run analysis using ARDL. Coefficients for error correction terms in all model specifications are negative and significant. This indicates that the model converges towards equilibrium. While the speed of adjustment is below fifty percent in each specification even it becomes twenty percent. The error correction (ECM) model shows a significant impact of capital in the current year and one year lagged on the 
economic growth in the short run. Indicators of governance do have effects on the gross domestic product in the short run.

\subsection{Panel ARDL, Long Run Results (Governance and FDI)}

In table 3 long run results for factors of FDI are given for four different model specifications with variations in the dimensions of institutional factors. As stated in the introduction and literature review, the institutional environment of the country can also influence the foreig $n$ direct investment in the host country. Results for institutional governance reveal that institutional governance in terms of control of corruption and rule of law may have positive as well as negative impacts on foreign direct investment. Model 3, in which institutional governance is used individually as a dimension of governance, institutional quality has a negative impact on FDI meaning that greater control on corruption may lead to a decreased level of FDI. In other words, an increase in corruption causes the FDI to increase. An increase in corruption may be an incentive for investors to invest in the host country (Egger $\&$ Winner, 2005). This negative impact of institutional governance on FDI supports the "helping hand" hypothesis (Quazi, Vemuri, \& Soliman, 2014). This result is consistent with the theoretical hypothesis postulated by Glass and $\mathrm{Wu}$ (2002). This negative relationship between institutional governance (control of corruption and rule of law) corruption and FDI contrasts with the traditional negative relationship of corruption and FDI highlighted in studies (Habib \& Zurawicki, 2002; Paudel, 2016; Zeshan \& Talat, 2014).

Table 5: Long Run Results of Panel ARDL (Dependent Variable: Foreign Direct Investment)

\begin{tabular}{|c|c|c|c|c|c|c|c|c|}
\hline Model No. & 1 & 2 & 3 & 4 & 5 & 6 & 7 & 8 \\
\hline $\begin{array}{c}\text { (Lag } \\
\text { Length) }\end{array}$ & $\begin{array}{c}(2,2,2,2, \\
2)\end{array}$ & $\begin{array}{c}(2,2,2,2, \\
2)\end{array}$ & $\begin{array}{c}(2,2,2,2, \\
2)\end{array}$ & $\begin{array}{c}(2,2,2,2, \\
2)\end{array}$ & $\begin{array}{c}(2,2,2,2, \\
2)\end{array}$ & $\begin{array}{c}(2,2,2,2, \\
2)\end{array}$ & $\begin{array}{c}(2,2,2,2, \\
2)\end{array}$ & $\begin{array}{c}(2,2,2,2,2,2,2 \\
2)\end{array}$ \\
\hline \multirow{2}{*}{ Capital } & 0.9731 & 0.7677 & 0.6763 & 0.6699 & 0.6578 & 0.9718 & 0.6922 & 0.8228 \\
\hline & $(0.0000)^{*}$ & $(0.0000)^{*}$ & $(0.0000)^{*}$ & $(0.0000)^{*}$ & $(0.0000)^{*}$ & $(0.0000)^{*}$ & $(0.0000)^{*}$ & $(0.0000)^{*}$ \\
\hline \multirow[b]{2}{*}{ Labor } & 0.9952 & 2.1072 & 1.0374 & 0.9754 & 1.6177 & 1.0822 & 0.3462 & 1.1144 \\
\hline & $(0.0175)^{*}$ & $(0.0000)^{*}$ & $(0.0081)$ & $(0.0044)^{*}$ & $(0.0000)^{*}$ & $(0.0099)^{*}$ & $(0.0000)^{*}$ & $(0.0060)^{*}$ \\
\hline \multirow{2}{*}{$\begin{array}{c}\text { Trade } \\
\text { openness }\end{array}$} & 1.0703 & 0.6853 & 1.7238 & 2.1251 & 2.1028 & 1.0660 & 2.2877 & 1.6316 \\
\hline & $(0.0011)^{*}$ & $(0.0000)^{*}$ & $(0.0000)^{*}$ & $(0.0000)^{*}$ & $(0.0000)^{*}$ & $(0.0000)^{*}$ & $(0.0000)^{*}$ & $(0.0000)^{*}$ \\
\hline Political & 0.0282 & & & & & & & 0.2419 \\
\hline $\begin{array}{c}\text { Governanc } \\
\mathrm{e}\end{array}$ & $(0.7356)$ & - & - & - & - & - & - & $(0.0465)^{* * *}$ \\
\hline Economic & & 0.8105 & & & & & & 0.4301 \\
\hline $\begin{array}{c}\text { Governanc } \\
\mathrm{e}\end{array}$ & - & $(0.0000)^{*}$ & - & - & - & - & - & $(0.0056)^{*}$ \\
\hline $\begin{array}{l}\text { Institution } \\
\text { al } \\
\text { Governanc } \\
\text { e }\end{array}$ & - & - & $\begin{array}{c}-0.4273 \\
(0.0002)^{*}\end{array}$ & - & - & - & - & $\begin{array}{c}0.7028 \\
(0.0002)^{* *}\end{array}$ \\
\hline $\begin{array}{c}\text { Overall } \\
\text { Governanc } \\
\text { e }\end{array}$ & - & - & - & $\underset{*}{(0.0549)^{*}}$ & - & - & - & - \\
\hline
\end{tabular}




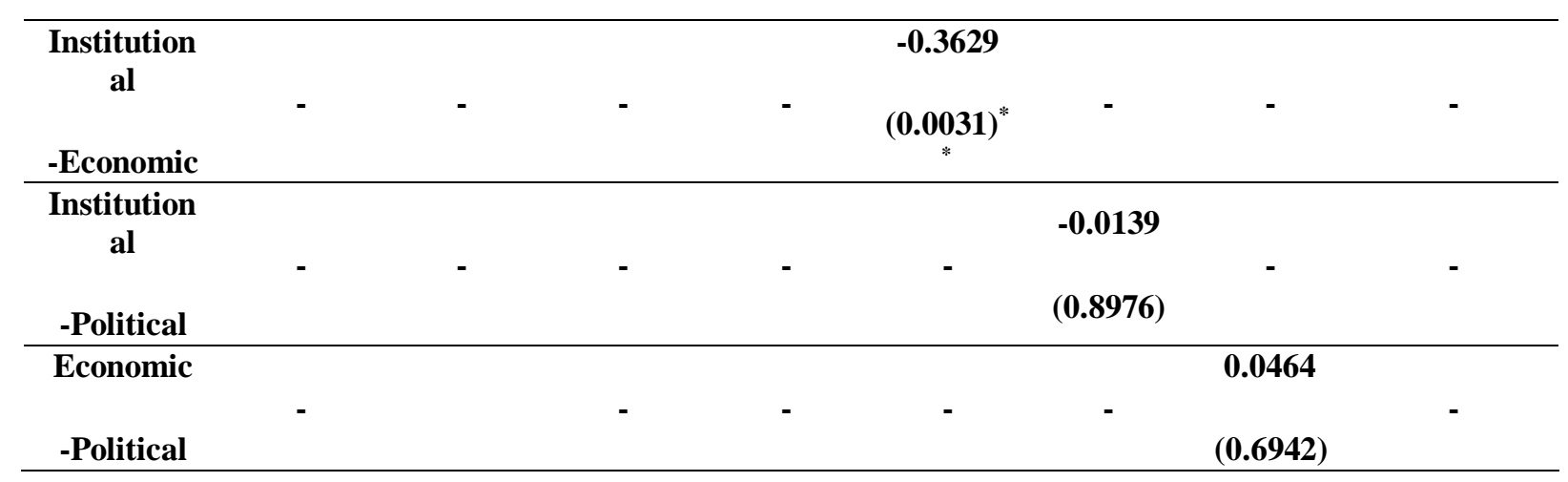

Source: Author's estimation based on WDI \& WGI Data by using Eviews-9.

Note: * and ** represents 1 and 5 percent level of significance correspondingly. Probabilities for each coefficient are given in parentheses.

When institutional governance is used in model 8 with other governance indicators, a sign of coefficient becomes positive meaning that institutional governance has a positive and significant impact on FDI. This result is consistent with the traditional view that decreased level of corruption can increase the level of foreign direct investment in the host country. These results are the same as were obtained in previous studies (Gani, 2007; Habib \& Zurawicki, 2002; Hoa \& Lin, 2016; Paudel, 2016; Zeshan \& Talat, 2014). Therefore, it can be inferred from the empirical results of this study that improved institutional quality may have positive as well as negative impacts on foreign direct investment depending upon the level of quality institutions and good governance as well as the level of development on the country.

Economic governance has a positive impact on foreign direct investment but this positive and significant impact when it is used as the sole indicator of governance. Results presented in the table shows that EGOV has also a positive and significant impact on FDI accompanied by other dimensions of governance meaning that formulating effective policies are important but implementation and trust of investors in domestic police and judiciary does matter, only then the government can be effective to attract new foreign direct investment in the host country. This positive and significant impact on governments' economic effectiveness on FDI is in line with the previous studies (Gani, 2007; Globerman et al., 2006; Hoa \& Lin, 2016; Paudel, 2016; Zeshan \& Talat, 2014).

In this study, political governance has also a positive but minor and insignificant effect on FDI as the value of the coefficient for political governance is 0.0282 in model 1 . Moreover, this impact is significant and in model 8 at a $1 \%$ level of significance when political governance is used with other dimensions of governance. Meaning that political governance does matter only when other indicators of governance improve. This relationship between political governance and FDI is an indication that political stability, having trust in government affairs and the likelihood of absence of terror and fear can induce the foreign investors to invest in such countries where political stability and freedom to speech is at maximum level. This finding is consistent with the previous findings (Bénassy-Quéré et al., 2007; Gani, 2007; Globerman et al., 2006; Hoa \& Lin, 2016; Paudel, 2016; Zeshan \& Talat, 2014). 


\subsection{Panel ARDL, Short Run Results (Governance and FDI)}

Short run ARDL results for macroeconomic and governance determinants of foreign direct investment are given in table 4 . The negative sign of coefficients for the error correction term is an indication that the model converges towards its equilibrium. The speed of adjustment is more than sixty percent in all model specifications. The governance indicators do not seem to have an impact on FDI in the short run hence we can say that countries must build their institutions for a long time only then good governance can be translated into a high level of foreign direct investment in Asian countries.

\section{Table 6: Panel ARDL, Short Run Results (Dependent Variable: Foreign Direct Investment)}

\begin{tabular}{|c|c|c|c|c|c|c|c|c|}
\hline $\begin{array}{l}\text { Model No. } \\
\text { (Lag } \\
\text { Length) }\end{array}$ & $\begin{array}{l}1 \\
(2,2,2,2,2)\end{array}$ & $(2,2,2,2,2)$ & $(2,2,2,2,2)$ & $\begin{array}{l}4 \\
(2,2,2,2,2)\end{array}$ & $(2,2,2,2,2)$ & $\begin{array}{l}6 \\
(2,2,2,2,2)\end{array}$ & $\begin{array}{l}7 \\
(2,2,2,2,2)\end{array}$ & $\begin{array}{l}8 \\
(2,2,2,2,2,2,2)\end{array}$ \\
\hline \multirow{2}{*}{ ECT } & -0.6268 & -0.8399 & -6468 & -0.6479 & -0.6822 & -0.6209 & -0.6596 & -0.6748 \\
\hline & $(0.0000)$ & $(0.0000)$ & $(0.0000)$ & $(0.0000)$ & $(0.0000)$ & $(0.0000)$ & $(0.0000)$ & $(0.0000)$ \\
\hline \multirow{2}{*}{$\begin{array}{l}\text { D (FDI (- } \\
1))\end{array}$} & 0.0494 & 0.1575 & 0.0323 & 0.0118 & 0.0492 & 0.0544 & 0.0693 & 0.0571 \\
\hline & $(0.4387)$ & $(0.0302)$ & $(0.6658)$ & $(0.8675)$ & $(0.5136)$ & $(0.4193)$ & $(0.6136)$ & $(0.4421)$ \\
\hline \multirow{2}{*}{$\begin{array}{l}\text { D } \\
\text { (Capital) }\end{array}$} & 4.0996 & 5.2219 & 4.5259 & 4.3657 & 4.4982 & 5.0544 & 4.3227 & 2.2492 \\
\hline & $(0.1324)$ & $(0.0926)$ & $(0.0665)$ & $(0.0847)$ & $(0.0874)$ & $(0.0863)$ & $(0.0641)$ & $(0.4230)$ \\
\hline \multirow{2}{*}{$\begin{array}{l}\text { D (Capital } \\
(-1))\end{array}$} & 2.5574 & 2.6907 & 2.4767 & 2.2702 & 2.4232 & 2.9678 & 3.8661 & 5.1687 \\
\hline & $(0.3622)$ & $(0.3846)$ & $(0.1963)$ & $(0.3432)$ & $(0.3730)$ & $(0.1684)$ & $(0.1710)$ & $(0.1401)$ \\
\hline \multirow{2}{*}{ D (Labor) } & -6.4231 & -10.6375 & 12.8662 & 15.7801 & 10.7919 & 3.8160 & -12.8645 & -49.8338 \\
\hline & $(0.7252)$ & $(0.5809)$ & $(0.4037)$ & $(0.3054)$ & $(0.5173)$ & $(0.9073)$ & $(0.7098)$ & $(0.2086)$ \\
\hline \multirow{2}{*}{$\begin{array}{l}\text { D (Labor } \\
(-1))\end{array}$} & 18.3794 & 47.3248 & 14.3887 & -6.3571 & 23.4896 & 17.4467 & 71.0327 & 94.6855 \\
\hline & $(0.7688)$ & $(0.6045)$ & $(0.7455)$ & $(0.9156)$ & $(0.7402)$ & $(0.7784)$ & $(0.3014)$ & $(0.3415)$ \\
\hline \multirow{2}{*}{$\mathrm{D}(\mathrm{T} \mathrm{O})$} & -7.6103 & -6.2777 & -4.5396 & -6.1590 & -5.6134 & -5.8117 & -4.2495 & -5.4871 \\
\hline & $(0.2176)$ & $(0.3578)$ & $(0.4022)$ & $(0.2982)$ & $(0.3662)$ & $(0.3011)$ & $(0.3891)$ & $(0.2925)$ \\
\hline \multirow{2}{*}{$\begin{array}{l}\mathrm{D}(\mathrm{T} \\
1)\end{array}$} & -8.9322 & -9.3005 & -3.7133 & -5.5955 & -6.8497 & -7.3927 & -4.5619 & -10.3091 \\
\hline & $(0.2698)$ & $(0.2642)$ & $(0.4554)$ & $(0.3207)$ & $(0.2889)$ & $(0.3827)$ & $(0.3160)$ & $(0.3311)$ \\
\hline \multirow[b]{2}{*}{$\mathrm{D}$ (PGOV) } & -0.0805 & & & & & & & -0.4897 \\
\hline & (0.9331) & - & - & - & - & - & - & $(0.8779)$ \\
\hline \multirow{2}{*}{$\begin{array}{l}\text { D (PGOV } \\
(-1)\end{array}$} & -4.6523 & & & & & & & -3.0808 \\
\hline & $(0.1217)$ & - & - & - & - & - & - & $(0.1727)$ \\
\hline \multirow[b]{2}{*}{ D (EGOV) } & & 1.1358 & & & & & & -0.9407 \\
\hline & - & (0.2937) & - & - & - & - & - & $(0.6349)$ \\
\hline $\begin{array}{l}\text { D (EGOV } \\
(-1)\end{array}$ & - & $\begin{array}{l}0.9469 \\
(0.6037)\end{array}$ & - & - & - & - & - & $\begin{array}{l}-1.0015 \\
(0.5761)\end{array}$ \\
\hline
\end{tabular}




\begin{tabular}{|c|c|c|c|c|c|c|c|c|}
\hline D (IGOV) & - & - & $\begin{array}{l}-0.9484 \\
(0.2306)\end{array}$ & - & - & - & - & $\begin{array}{l}0.9701 \\
(0.2852)\end{array}$ \\
\hline $\begin{array}{l}\text { D (IGOV } \\
(-1)\end{array}$ & - & - & $\begin{array}{l}0.9542 \\
(0.4937)\end{array}$ & - & - & - & - & $\begin{array}{l}0.1177 \\
(0.9185)\end{array}$ \\
\hline $\mathrm{D}(\mathrm{GOV})$ & - & - & & $\begin{array}{l}1.2378 \\
(0.0553)\end{array}$ & - & - & - & \\
\hline $\begin{array}{l}\mathrm{D}(\mathrm{GOV} \text { (- } \\
\text { 1) }\end{array}$ & - & - & - & $\begin{array}{l}1.4765 \\
(0.2901)\end{array}$ & - & - & - & - \\
\hline $\begin{array}{l}\text { D } \\
\left(I^{*} \mathrm{EGOV}\right)\end{array}$ & - & - & - & - & $\begin{array}{l}1.4368 \\
(0.0914)\end{array}$ & - & - & - \\
\hline $\begin{array}{l}\text { D } \\
\left(I^{*} \mathrm{EGOV}\right. \\
(-1)\end{array}$ & - & - & - & - & $\begin{array}{l}1.6801 \\
(0.3883)\end{array}$ & - & - & - \\
\hline $\begin{array}{l}\text { D } \\
\left(I^{*} \mathrm{PGOV}\right)\end{array}$ & - & - & - & - & - & $\begin{array}{l}1.9173 \\
(0.2758)\end{array}$ & - & - \\
\hline $\begin{array}{l}\text { D } \\
\left(I^{*} \mathrm{PGOV}\right. \\
(-1)\end{array}$ & - & - & - & - & - & $\begin{array}{l}1.2753 \\
(0.3912)\end{array}$ & - & - \\
\hline $\begin{array}{l}\text { D } \\
\left(\mathrm{E}^{*} \mathrm{PGOV}\right)\end{array}$ & - & - & - & - & - & & $\begin{array}{l}3.0703 \\
(0.0400)\end{array}$ & - \\
\hline $\begin{array}{l}\text { D } \\
\left(\mathrm{E}^{*} \mathrm{PGOV}\right. \\
(-1)\end{array}$ & - & - & - & - & - & & $\begin{array}{l}-0.5448 \\
(0.5429)\end{array}$ & - \\
\hline Constant & $\begin{array}{l}-12.7383 \\
(0.0000)\end{array}$ & $\begin{array}{l}-29.8746 \\
(0.0000)\end{array}$ & $\begin{array}{c}-10.3663 \\
(0.0000)\end{array}$ & $\begin{array}{l}-9.8802 \\
(0.0000)\end{array}$ & $\begin{array}{l}-18.4213 \\
(0.0000)\end{array}$ & $\begin{array}{c}-13.4377 \\
(0.0000)\end{array}$ & $\begin{array}{l}-4.1846 \\
(0.0000)\end{array}$ & $\begin{array}{l}9.2801 \\
(0.0004)\end{array}$ \\
\hline
\end{tabular}

Source: Author's estimation based on WDI \& WGI Data by using Eviews-9.

Note: * and $* *$ represents 1 and 5 percent level of significance correspondingly. Probabilities for each coefficient are given in parentheses.

\subsection{Panel Causality Test}

Results of the panel homogeneous causality test are given in table 6 which shows the existence of bi-directional causality running from all three governance dimensions (institutional, economic and political governance) to gross domestic product. It is revealed from these results that overall good governance leads to economic growth. But no evidence of causality from GDP to governance is found which is against the view that better income levels lead to better institutions. This conclusion is consistent with the findings of Asghar et al. (2020). 


\section{Conclusion and Policy Recommendations}

As the objective of the study was to find out the impact of governance on the gross domestic product, we found a significant impact of governance on GDP. Gross fixed capital formation has a positive and significant impact on economic growth (GDP) not only in long run but in the short run also. Political governance and economic governance affect GDP positively and significantly which is consistent with findings of previous studies (Haggard \& Tiede, 2011; Huang \& Ho, 2017; Ouédraogo, 2017).

Long run results for determinants of foreign direct investment pointed out the positive and significant impact of capital on FDI in long as well as short run, labor has also a positive and significant impact on FDI and these results are in line with those of Adhikary (2011) and Anyanwu and Yameogo (2015). Trade openness also influences foreign direct investment positively and significantly in the long run. Institutional governance has negative as well as a positive impact on FDI but significance varies to different specifications. The negative impact of institutional governance is consistent with the findings of Glass and Wu (2002) and Egger and Winner (2005). It is the perception behind the negative impact of control of corruption that corruption serves as an incentive for investors to invest in the host country. The positive impact of institutional governance on FDI is significant in the eighth model which is broad model. This positive impact is in line with the results of Gani (2007); Zeshan and Talat (2014); Hoa and Lin (2016) and Paudel (2016). Homogeneous panel causality tests' results reveal that there is bi-directional causality from political, economic, and institutional governance to gross domestic product. The most interesting thing in panel causality results is the existence of bi-directional causality among different dimensions of governance meaning that each dimension of governance stimulates the others.

Keeping in view the results of this study, pro-growth institutions should be created, already working institutions should be strengthened and the level of corruption should be reduced through improvements in the overall governance structure. Removing or curbing the corruption will turn the institutions efficient necessary to formulate and implement the economic policies. These effective economic policies will not only attract FDI but can also be helpful to gain a competitive advantage. Moreover, efficient institutes "free from corruption" will also be helpful in the collection of tax revenues which can be used for developmental projects in the country resulting in employment and a high level of economic output. Although our results relating to the impacts of control of corruption in GDP and FDI are negative it does not mean that countries should promote corruption. One possible reason for this impact is inefficiencies in government and the absence of rule of law in the respective countries. Therefore, the government should take measures to control corruption along with improvements in the other dimensions of governance. Quality of government in terms of delivery of public goods and services and effective policy making also does matter. Information and communication technologies (ICT) should be introduced in the provisioning process of public and civil services. Consequently, government effectiveness will be improved and the confidence level of businessmen, consumers and investors will be boosted to contribute to economic activities in the countries. To maintain the rule of law, police and courts should be independent and free from political influence. Such a legal framework should be established which can be helpful to enforce the contracts and protect the property rights only then citizens will have confidence in the police, courts and legal system of the country. Access to free and timely justice should be promoted. 
Table 7: Results of Panel Homogeneous Causality Tests

\begin{tabular}{|c|c|c|c|c|c|c|c|c|c|c|c|c|c|c|c|c|}
\hline \multirow{2}{*}{$\begin{array}{l}\text { Vari } \\
\text { ables }\end{array}$} & \multicolumn{2}{|c|}{ GDP } & \multicolumn{2}{|l|}{ FDI } & \multicolumn{2}{|c|}{ Capital } & \multicolumn{2}{|c|}{ Labor } & \multicolumn{2}{|l|}{ TO } & \multicolumn{2}{|c|}{ IGOV } & \multirow{2}{*}{$\begin{array}{l}\text { EG } \\
\text { OV } \\
\text { Pro } \\
\text { b. }\end{array}$} & \multicolumn{2}{|c|}{ PGOV } & \multirow[b]{2}{*}{$\begin{array}{l}\text { Dec } \\
\text { sion }\end{array}$} \\
\hline & $\begin{array}{l}\text { Pro } \\
\text { b. }\end{array}$ & $\begin{array}{l}\text { Deci } \\
\text { sion }\end{array}$ & $\begin{array}{l}\text { Pro } \\
\text { b. }\end{array}$ & $\begin{array}{l}\text { Deci } \\
\text { sion }\end{array}$ & $\begin{array}{l}\text { Pro } \\
\text { b. }\end{array}$ & $\begin{array}{l}\text { Deci } \\
\text { sion }\end{array}$ & $\begin{array}{l}\text { Pro } \\
\text { b. }\end{array}$ & $\begin{array}{l}\text { Deci } \\
\text { sion }\end{array}$ & $\begin{array}{l}\text { Pro } \\
\text { b. }\end{array}$ & $\begin{array}{l}\text { Deci } \\
\text { sion }\end{array}$ & $\begin{array}{l}\text { Pro } \\
\text { b. }\end{array}$ & $\begin{array}{l}\text { Deci } \\
\text { sion }\end{array}$ & & $\begin{array}{l}\text { Deci } \\
\text { sion }\end{array}$ & $\begin{array}{l}\text { Pro } \\
\text { b. }\end{array}$ & \\
\hline GDP & - & - & $\begin{array}{l}0.38 \\
83\end{array}$ & No & $\begin{array}{l}0.3 \\
819\end{array}$ & No & $\begin{array}{l}0.01 \\
17^{* *}\end{array}$ & Yes & $\begin{array}{l}0.72 \\
28\end{array}$ & No & $\begin{array}{l}0.07 \\
51^{* * *}\end{array}$ & Yes & $\begin{array}{l}0.0 \\
073\end{array}$ & Yes & $\begin{array}{l}0.00 \\
45\end{array}$ & Yes \\
\hline FDI & $\begin{array}{l}0.0 \\
000 \\
*\end{array}$ & Yes & - & - & $\begin{array}{l}0.0 \\
000 \\
*\end{array}$ & Yes & $\begin{array}{l}0.26 \\
41\end{array}$ & No & $\begin{array}{l}0.72 \\
83\end{array}$ & No & $\begin{array}{l}0.71 \\
28\end{array}$ & No & $\begin{array}{l}0.0 \\
075\end{array}$ & Yes & $\begin{array}{l}0.50 \\
30\end{array}$ & No \\
\hline $\begin{array}{l}\text { Capi } \\
\text { tal }\end{array}$ & $\begin{array}{l}0.0 \\
002 \\
*\end{array}$ & Yes & $\begin{array}{l}0.94 \\
88\end{array}$ & No & - & - & $\begin{array}{l}0.00 \\
56^{*}\end{array}$ & Yes & $\begin{array}{l}0.87 \\
55\end{array}$ & No & $\begin{array}{l}0.19 \\
27\end{array}$ & No & $\begin{array}{l}0.3 \\
526\end{array}$ & No & $\begin{array}{l}0.29 \\
51\end{array}$ & No \\
\hline $\begin{array}{l}\text { Labo } \\
\mathrm{r}\end{array}$ & $\begin{array}{l}0.5 \\
923\end{array}$ & No & $\begin{array}{l}0.51 \\
04\end{array}$ & No & $\begin{array}{l}0.7 \\
877\end{array}$ & No & - & - & $\begin{array}{l}0.05 \\
22^{* * *}\end{array}$ & Yes & $\begin{array}{l}0.08 \\
57^{* * *}\end{array}$ & Yes & $\begin{array}{l}0.0 \\
062 \\
*\end{array}$ & Yes & $\begin{array}{l}0.98 \\
43\end{array}$ & No \\
\hline TO & $\begin{array}{l}0.5 \\
438\end{array}$ & No & $\begin{array}{l}0.67 \\
83\end{array}$ & No & $\begin{array}{l}0.7 \\
074\end{array}$ & No & $\begin{array}{l}0.68 \\
74\end{array}$ & No & - & - & $\begin{array}{l}0.25 \\
39\end{array}$ & No & $\begin{array}{l}0.1 \\
050\end{array}$ & No & $\begin{array}{l}0.09 \\
95^{* * *}\end{array}$ & Yes \\
\hline $\begin{array}{l}\text { IGO } \\
\text { V }\end{array}$ & $\begin{array}{l}0.1 \\
759\end{array}$ & No & $\begin{array}{l}0.21 \\
33\end{array}$ & No & $\begin{array}{l}0.2 \\
474\end{array}$ & No & $\begin{array}{l}0.31 \\
20\end{array}$ & No & $\begin{array}{l}0.07 \\
45^{* * *}\end{array}$ & Yes & - & - & $\begin{array}{l}0.0 \\
051 \\
*\end{array}$ & Yes & $\begin{array}{l}0.00 \\
11^{*}\end{array}$ & Yes \\
\hline $\begin{array}{l}\text { EGO } \\
\text { V }\end{array}$ & $\begin{array}{l}0.2 \\
138\end{array}$ & No & $\begin{array}{l}0.09 \\
94^{* * *}\end{array}$ & Yes & $\begin{array}{l}0.2 \\
419\end{array}$ & No & $\begin{array}{l}0.15 \\
14\end{array}$ & No & $\begin{array}{l}0.12 \\
90\end{array}$ & No & $\begin{array}{l}0.06 \\
64^{* *}\end{array}$ & Yes & - & - & $\begin{array}{l}0.00 \\
54^{*}\end{array}$ & Yes \\
\hline $\begin{array}{l}\text { PGO } \\
\mathrm{V}\end{array}$ & $\begin{array}{l}0.6 \\
452\end{array}$ & No & $\begin{array}{l}0.11 \\
60\end{array}$ & No & $\begin{array}{l}0.7 \\
117\end{array}$ & No & $\begin{array}{l}0.03 \\
12^{* *}\end{array}$ & Yes & $\begin{array}{l}0.04 \\
67^{* *}\end{array}$ & Yes & $\begin{array}{l}0.00 \\
00^{*}\end{array}$ & Yes & $\begin{array}{l}0.0 \\
029 \\
*\end{array}$ & Yes & - & - \\
\hline
\end{tabular}

Source: Author's estimation based on WDI \& WGI Data.

Note: $*$ and ${ }^{* *}$ represents 1 and 5 percent level of significance correspondingly. Probabilities for each coefficient are given in parentheses.

\section{References}

Adhikary, B. K. (2011). FDI, trade openness, capital formation, and economic growth in Bangladesh: a linkage analysis. International Journal of Business and Management, 6(1), 16-28.

Ahmad, R., Bashir, F., \& Hussain, A. (2018). Human capital, governance and poverty reduction: A panel data analysis. Review of Economics and Development Studies, 4(1), 103-113.

Anyanwu, J. C., \& Yameogo, N. D. (2015). What drives foreign direct investments into West Africa? An empirical investigation. African Development Review, 27(3), 199-215.

Aparicio, S., Urbano, D., \& Audretsch, D. (2016). Institutional factors, opportunity entrepreneurship and economic growth: Panel data evidence. Technological forecasting and social change, 102, 45-61.

Asghar, N., Qureshi, D. S., \& Nadeem, M. (2020). Institutional quality and economic growth: Panel ARDL analysis for selected developing economies of Asia. South Asian Studies, 30(2), 381-404. 
Azam, M., \& Emirullah, C. (2014). The role of governance in economic development: evidence from some selected countries in Asia and the Pacific. International Journal of Social Economics, 41(12), 1265-1278.

Bénassy-Quéré, A., Coupet, M., \& Mayer, T. (2007). Institutional determinants of foreign direct investment. World economy, 30(5), 764-782.

Bhattacharjee, J., \& Haldar, S. K. (2015). Economic growth of selected South Asian countries: Does institution matter? Asian Economic and Financial Review, 5(2), 356370 .

Bjørnskov, C. (2012). How does social trust affect economic growth? Southern Economic Journal, 78(4), 1346-1368.

Cooray, A. (2009). Government expenditure, governance and economic growth. Comparative Economic Studies, 51(3), 401-418.

Egger, P., \& Winner, H. (2005). Evidence on corruption as an incentive for foreign direct investment. European journal of political economy, 21(4), 932-952.

ESCAP, U. (2017). Economic and social survey of Asia and the Pacific 2017: governance and fiscal management (9211207428). Retrieved from

Farooq, A., Shahbaz, M., Arouri, M., \& Teulon, F. (2013). Does corruption impede economic growth in Pakistan? Economic Modelling, 35, 622-633.

Fischer, S., Alonso-Gamo, P., \& Von Allmen, U. E. (2001). Economic developments in the West Bank and Gaza since Oslo. The Economic Journal, 111(472), 254-275.

Gani, A. (2007). Governance and foreign direct investment links: evidence from panel data estimations. Applied economics letters, 14(10), 753-756.

Gani, A. (2011). Governance and growth in developing countries. Journal of Economic Issues, 45(1), 19-40.

Glass, A. J., \& Wu, X. (2002). Does corruption discourage foreign direct investment and innovation. Unpublished manuscript, Department of Economics, Texas A\&M University.

Globerman, S., \& Shapiro, D. (2003). Governance infrastructure and US foreign direct investment. Journal of international business studies, 34(1), 19-39.

Globerman, S., Shapiro, D., \& Tang, Y. (2006). Foreign direct investment in emerging and transition European countries: Emerald Group Publishing Limited.

Habib, M., \& Zurawicki, L. (2002). Corruption and foreign direct investment. Journal of international business studies, 33(2), 291-307.

Habtamu, F. N. (2008). Roles of Governance in explaining economic growth in sub-Saharan Africa. Africa Policy Journal, 4, 1-21.

Haggard, S., \& Tiede, L. (2011). The rule of law and economic growth: where are we? World Development, 39(5), 673-685.

Haidar, J. I. (2012). The impact of business regulatory reforms on economic growth. Journal of the Japanese and international economies, 26(3), 285-307.

Haider, A., ud Din, M., \& Ghani, E. (2011). Consequences of political instability, governance and bureaucratic corruption on inflation and growth: The case of Pakistan. The Pakistan Development Review, 50(4), 773-807.

Haq, R., Zia, U., \& Arif, G. (2006). Governance and Pro-poor Growth: Evidence from Pakistan. The Pakistan Development Review, 45(4), 761-776.

Hoa, D. T. T., \& Lin, J.-Y. (2016). Determinants of foreign direct investment in Indochina: A holistic approach. International Journal of Business and Applied Social Science, 2(1), $1-10$.

Huang, C.-J. (2016). Is corruption bad for economic growth? Evidence from Asia-Pacific countries. The North American Journal of Economics and Finance, 35, 247-256. 
Huang, C.-J., \& Ho, Y.-H. (2017). Governance and economic growth in Asia. The North American Journal of Economics and Finance, 39, 260-272.

Jellal, M., Mohamed, B., \& Asongu, S. (2016). Institutional Governance, Education and Growth. Theoretical Economics Letters, 131-137.

Kaufmann, D., Kraay, A., Lora, E., \& Pritchett, L. (2002). Growth without governance. Economia, 3(1), 169-229.

Long, C., Yang, J., \& Zhang, J. (2015). Institutional impact of foreign direct investment in China. World Development, 66, 31-48.

Méon, P.-G., \& Sekkat, K. (2005). Does corruption grease or sand the wheels of growth? Public choice, 122(1), 69-97.

Nazir, R., \& Anwar, M. (2013). Growth governance nexus: A case of Pakistan. Journal of Economics and Behavioral Studies, 5(8), 562-572.

Ouédraogo, I. M. (2017). Governance, corruption, and the informal economy. Modern Economy, 8(2), 256-271.

Paudel, R. (2016). Role of Human Development and Governance in Foreign Direct Investment in the Post Reform Era: The Case of Tanzania. International Journal of Research \& Methodology in Social Science, 2(2), 5-18.

Pushak, T., Tiongson, E. R., \& Varoudakis, A. (2007). Public finance, governance, and growth in transition economies: Empirical evidence from 1992-2004.

Quazi, R., Vemuri, V., \& Soliman, M. (2014). Impact of corruption on foreign direct investment in Africa. International Business Research, 7(4), 1.

Sarwar, K., Afzal, M., Shafiq, M., \& Rehman, H. (2013). Institutions and economic growth in South Asia. Journal of Quality and Technology Management, 9(2), 01-23.

Vītola, A., \& Šenfelde, M. (2014). Evaluation of institutions in innovation-driven economies. Paper presented at the 16th International Scientific Conference "Economic Science for Rural Development

Wedeman, A. (1997). Looters, rent-scrapers, and dividend-collectors: Corruption and growth in Zaire, South Korea, and the Philippines. The journal of developing areas, 31(4), 457-478.

Wilson, R. (2016). Does governance cause growth? Evidence from China. World Development, 79, 138-151.

Yerrabati, S., \& Hawkes, D. (2015). Economic Governance and Economic Growth in South and East Asia \& Pacific Region: Evidence from Systematic Literature Reviews and Metaanalysis. Advances in Economics and Business, 3(1), 1-21.

Zeshan, A., \& Talat, A. (2014). Impact of governance indicators on FDI inflows: Empirical evidence from Pakistan. Caspian Journal of Applied Sciences Research, 3(9), 16-23.

Zubair, D. S. S., \& Khan, M. (2014). Good governance: Pakistan's economic growth and Worldwide Governance Indicators. Pakistan Journal of Commerce and Social Sciences, 8(1), 258-271. 


\section{APPENDIX-A}

\section{List of Asian Countries Selected for the Study}

\begin{tabular}{|c|c|c|c|c|c|c|}
\hline S.No. & Country & Region & Corruption & CPI & \multicolumn{2}{|c|}{ Income Level } \\
\hline & & & $\begin{array}{l}\text { Perception } \\
\text { Index }\end{array}$ & & & \\
\hline 1 & China & East Asia & $40 / 100$ & $79 / 176$ & $\begin{array}{l}\text { Upper } \\
\text { Income }\end{array}$ & Middle \\
\hline 2 & Oman & $\begin{array}{l}\text { Middle East/ South } \\
\text { West }\end{array}$ & $45 / 100$ & $64 / 176$ & High Inc & \\
\hline 3 & $\begin{array}{l}\text { Saudi } \\
\text { Arabia }\end{array}$ & $\begin{array}{l}\text { Middle East/ South } \\
\text { West }\end{array}$ & $46 / 100$ & $62 / 176$ & High Inc & \\
\hline 4 & Indonesia & South East Asia & $37 / 100$ & $90 / 176$ & $\begin{array}{l}\text { Lower } \\
\text { Income }\end{array}$ & Middle \\
\hline 5 & Thailand & South East Asia & $35 / 100$ & $101 / 176$ & $\begin{array}{l}\text { Upper } \\
\text { Income }\end{array}$ & Middle \\
\hline 6 & Malaysia & South East Asia & $49 / 100$ & $55 / 176$ & $\begin{array}{l}\text { Upper } \\
\text { Income }\end{array}$ & Middle \\
\hline 7 & Vietnam & South East Asia & $33 / 100$ & $113 / 176$ & $\begin{array}{l}\text { Lower } \\
\text { Income }\end{array}$ & Middle \\
\hline 3 & $\begin{array}{l}\text { South } \\
\text { Korea }\end{array}$ & East Asia & $53 / 100$ & $52 / 176$ & High Inc & \\
\hline 9 & Cambodia & South East Asia & $21 / 100$ & $156 / 176$ & $\begin{array}{l}\text { Lower } \\
\text { Income }\end{array}$ & Middle \\
\hline 10 & India & South Asia & $40 / 100$ & $79 / 176$ & $\begin{array}{l}\text { Lower } \\
\text { Income }\end{array}$ & Middle \\
\hline 11 & Pakistan & South Asia & $32 / 100$ & $116 / 176$ & $\begin{array}{l}\text { Lower } \\
\text { Income }\end{array}$ & Middle \\
\hline 12 & Bangladesh & South Asia & $26 / 100$ & $145 / 176$ & $\begin{array}{l}\text { Lower } \\
\text { Income }\end{array}$ & Middle \\
\hline 13 & Sri Lanka & South Asia & $36 / 100$ & $95 / 176$ & $\begin{array}{l}\text { Lower } \\
\text { Income }\end{array}$ & Middle \\
\hline 14 & Nepal & South Asia & $29 / 100$ & $131 / 176$ & Low Inc & \\
\hline 15 & Russia & Central Asia & $29 / 100$ & $131 / 176$ & $\begin{array}{l}\text { Upper } \\
\text { Income }\end{array}$ & Middle \\
\hline 16 & Iran & Central Asia & $29 / 100$ & $131 / 176$ & $\begin{array}{l}\text { Upper } \\
\text { Income }\end{array}$ & Middle \\
\hline 17 & Kazakhstan & Central Asia & $29 / 100$ & $131 / 176$ & $\begin{array}{l}\text { Upper } \\
\text { Income }\end{array}$ & Middle \\
\hline 18 & Mongolia & Central Asia & $38 / 100$ & $87 / 176$ & $\begin{array}{l}\text { Lower } \\
\text { Income }\end{array}$ & Middle \\
\hline 19 & $\begin{array}{l}\text { Kyrgyz } \\
\text { Republic }\end{array}$ & Central Asia & $28 / 100$ & $136 / 176$ & $\begin{array}{l}\text { Lower } \\
\text { Income }\end{array}$ & Middle \\
\hline 20 & Tajikistan & Central Asia & $25 / 100$ & $151 / 176$ & $\begin{array}{l}\text { Lower } \\
\text { Income }\end{array}$ & Middle \\
\hline 21 & Georgia & $\begin{array}{l}\text { Middle East/ South } \\
\text { West }\end{array}$ & $57 / 100$ & $44 / 176$ & $\begin{array}{l}\text { Upper } \\
\text { Income }\end{array}$ & Middle \\
\hline 22 & Israel & Middle East/ South & $64 / 100$ & $28 / 176$ & High Inc & \\
\hline
\end{tabular}




\begin{tabular}{|c|c|c|c|c|c|c|}
\hline 23 & Japan & $\begin{array}{l}\text { West } \\
\text { East Asia }\end{array}$ & $72 / 100$ & $20 / 176$ & \multicolumn{2}{|c|}{ High Income } \\
\hline 24 & Azerbaijan & $\begin{array}{l}\text { Middle East/ South } \\
\text { West }\end{array}$ & $30 / 100$ & $123 / 1756$ & $\begin{array}{l}\text { Upper } \\
\text { Income }\end{array}$ & Middle \\
\hline 25 & Lebanon & $\begin{array}{l}\text { Middle East/ South } \\
\text { West }\end{array}$ & $28 / 100$ & $136 / 176$ & $\begin{array}{l}\text { Upper } \\
\text { Income }\end{array}$ & Middle \\
\hline 26 & Singapore & South East Asia & $84 / 100$ & $7 / 176$ & High In & \\
\hline
\end{tabular}

Author's Compilation 